\title{
Sex Hormone Binding Protein Measurement
}

National Cancer Institute

\section{Source}

National Cancer Institute. Sex Hormone Binding Protein Measurement. NCI Thesaurus. Code $C 74745$

The determination of the amount of sex hormone binding protein present in a sample. 